\title{
Landfill GHG Reduction through Different Microbial Methane Oxidation Biocovers
}

\author{
Isabella Pecorini * (D) and Renato Iannelli ${ }^{D}$ \\ DESTEC - Department of Energy, Systems, Territory and Construction Engineering, University of Pisa, \\ 56122 Pisa, Italy; renato.iannelli@unipi.it \\ * Correspondence: isabella.pecorini@unipi.it; Tel.: +39-050-221-7926
}

Received: 30 April 2020; Accepted: 12 May 2020; Published: 15 May 2020

\begin{abstract}
Emissions from daily and final covers of municipal solid waste (MSW) landfills can produce significant impacts on local and global environments. Simplifying, landfills can cause local impacts with odor emissions and global impacts with GHGs. This work focuses on hydrogen sulfide $\left(\mathrm{H}_{2} \mathrm{~S}\right)$ and methane $\left(\mathrm{CH}_{4}\right)$ emissions, with the aim of studying how it is possible to reduce their impacts by means of biofiltration systems. Both field and laboratory investigations have been carried out in Casa Rota Landfill (Tuscany, Italy). In the field trials, four pilot-scale biocovers made of compost from a source-selected organic fraction (SS compost), compost from a mechanical biological treatment plant-the residual fractions of the MSW, a mixed compost (SS-MSW compost) and sand were monitored in the daily cover area of the landfill, where high emissions were detected. Results showed that high $\mathrm{CH}_{4}$ and $\mathrm{H}_{2} \mathrm{~S}$ emissions reductions occurred in the mixed SS-MSW compost plot, given a maximum methane oxidation efficiency of greater than $98 \%$ and an average oxidation efficiency of about $75 \%$. To assess the specific oxidation rate, laboratory tests using SS-MSW compost sampled from the biocovers were done.
\end{abstract}

Keywords: microbial methane oxidation; landfill odor mitigation; biocovers; biofiltration systems; greenhouse gases emissions mitigation

\section{Introduction}

Landfills are considered important anthropogenic sources of odors and greenhouse gases, mainly due to uncontrolled biogas emissions. The odor pollution impact from landfill sites is often within $2.0 \mathrm{~km}$, but under bad conditions, such temperature inversion, it can go beyond $6.0 \mathrm{~km}$ [1]. Methane is a large potential contributor to climate change with a global warming potential of 21 [2].

Landfilling is still the most widely used form of disposal of municipal solid waste (MSW) in Europe. Eurostat shows that in 2018, on average, in the 28 member states, 23\% of MSW produced was disposed of in landfills [3,4]. With reference to 2018, in Italy the MSW disposed in landfill amounted to the $22 \%$ of the produced waste [5].

Biogas collection systems and daily and final covers are the used methods for emissions control [6], and several studies demonstrated that these two systems are highly dependent on each other: the rate of efficiency of the gas extraction system varies from $50 \%$ to $95 \%$ depending on the type of cover system (daily, intermediate or final) [7]. The conventional possibilities of reducing the greenhouse effect from waste landfilling consist of landfill gas flaring or combustion with energy recovery $[8,9]$. Furthermore, over time, with the natural decrease in biogas production and the reduction in the methane content [10], conventional treatment technologies become technically and economically unsuitable [11-13]. Biofiltration systems are considered effective alternatives in the management of landfill gas for both methane oxidation of fugitive emissions with low calorific value $[14,15]$ and for the mitigation of odorous compounds $[12,16,17]$. 
Researchers have found that, among the processes that naturally occur in the landfill covers, the presence of $\mathrm{CH}_{4}$ and $\mathrm{O}_{2}$ counter gradients provides the necessary conditions for the development of methanotrophic bacteria, able to degrade methane in landfill gas. As the investigation of microbial $\mathrm{CH}_{4}$ oxidation in landfill progressed, the potential to exploit the process in engineered systems was quickly recognized [18-21].

In particular, the environmental factors that could affect the process have been found to be: temperature [14,22-24], moisture content [25,26], micronutrient availability [18,27], material characteristics of the filter media [14,28,29] and climatic and inhibition conditions [30-32].

Biofiltration is one of the biological methods which is used for odor elimination $[16,33,34]$. Three important general factors determine compost biofilter performance: (a) the type of the filter media (including void fraction, particle size, moisture content, microbial diversity and nutrients), (b) the prevailing conditions of gas flow inside the biofiltration unit (including superficial velocity, gas distribution, temperature and inlet pressure) and (c) the substrate concentration, solubility and biodegradability $[7,18,33]$. Similarly to biological methane oxidation studies, also in this case, numerous researchers have studied the optimal process parameters and the performances of different filtering materials [35,36].

Since many factors influence the efficiency of the microbial oxidation processes of the landfill gas and it is difficult to define the process conditions [37], an innovative combined approach between the field pilot scale and the laboratory scale has been chosen here.

The aim of this study was to compare different types of biocover filter media produced by plants by treating the organic fraction of municipal solid waste, compost, for instance, in order to identify which performs best in terms of reducing methane emissions. This paper describes the results of field and laboratory investigations that have been carried out in Casa Rota Landfill (Tuscany, Italy). A pilot biocovers system was trialed to mitigate the uncontrolled emissions from the daily cover area. Compost from a source-selected organic fraction, MSW compost from a mechanical biological treatment plant, mixed compost and sand were compared in the experimental biocover. Furthermore, some laboratory column tests were carried out in order to assess the performances of the materials used in the field test with a known inlet biogas flow.

\section{Materials and Methods}

\subsection{Description of the Site}

Casa Rota Landfill is in the Province of Arezzo (Tuscany, Italy). In the landfill, non-hazardous municipal and industrial solid waste has been accepted from 2006 until now, with an average rate of $262,530 \mathrm{t} \mathrm{yr}^{-3}$. The total waste disposal capacity is 5.2 million $\mathrm{m}^{3}$ in its 11 cells, and it has a total surface area of about $190,000 \mathrm{~m}^{2}$. The active gas management system is composed of 126 vertical perforated wells, 52 horizontal drainage pipes and 33 dual leachate/gas extraction wells. The experimental biocover was constructed in the daily cover area of the landfill, where high emissions were detected. In general, the construction and management of the landfill studied complies with the European Landfill Directive [38].

\subsection{Biocovers System Design}

In order to construct the biocover system, the temporary cover (about $35 \mathrm{~cm}$ of compacted clay) was removed to enhance the gas flow up to the biocover.

The biocover system consisted of four plots of $25 \mathrm{~m}^{2}$ delimited by a clay bank. Each of the experimental plots included a $70 \mathrm{~cm}$ thick layer of substrate underlined by a $20 \mathrm{~cm}$ drainage layer of gravel. Plots were directly fed by the biogas produced by 1-year-old unsorted waste.

The materials used in the biocover were 1-year-old compost form source-selected organic fraction (SS compost), MSW compost from a mechanical biological treatment plant (MSW compost), a mixture of the previous compost (SS-MSW compost) and sand. The composts were mixed with sand with 
a volume ratio of 5:1, as suggested by Jugnia et al. (2008) [39]. All the materials were available in large amounts at the landfill, since a mechanical biological treatment and composting plant is near the landfill.

The organic matter content of the SS compost (loss of ignition at $550{ }^{\circ} \mathrm{C}$ ) was $27.4 \% \mathrm{w} / \mathrm{dw}$, the pH 7.1 and the dynamic respiration index (DRI) was $373 \mathrm{mgO}_{2} \mathrm{~h}^{-1} \mathrm{~kg}^{-1}$ of volatile solids (VS) [40,41]. An organic matter content of $23.3 \% \mathrm{w} / \mathrm{dw}$, a pH of 7.6 and a DRI of $427 \mathrm{mgO}_{2} \mathrm{~h}^{-1} \mathrm{~kg}^{-1} \mathrm{VS}$ were measured for the MSW compost. Respirometry tests were performed according to the UNI/TS 11184, and, as suggested by the standard, the obtained results are typical for biologically stable substrates [40,41].

Twenty-seven probes were installed into each plot to measure the soil gas concentration and the temperature at 15, 25, 35, 45, 55, 65 and $75 \mathrm{~cm}$ depths. Probes were assessed in triplicate for each plot and consisted of high-density polyethylene (HDPE) pipes each with an internal diameter of $8 \mathrm{~mm}$. In order to measure the gas composition outside the experimental area, 4 probes were externally installed at 25 and $35 \mathrm{~cm}$ depths next to each plot.

\subsection{Column Tests}

To assess the performances of the materials used in the field test with a known inlet biogas flow, some laboratory trials were done.

A column was constructed with an HDPE pipe with an external diameter of $250 \mathrm{~mm}$, a length of $1700 \mathrm{~mm}$ and a wall thickness of $16 \mathrm{~mm}$. The column was filled with a gas distribution layer of coarse gravel of $35 \mathrm{~cm}$ in thickness covered by about $105 \mathrm{~cm}$ of tested sample. From the bottom, the column was continuously fed with moisturized synthetic gas controlled by a flow meter, while on the top in the headspace, a fan was used for air-mixing. Vertically, 11 probes, consisting of HDPE pipes each with an internal diameter of $8 \mathrm{~mm}$ and a length of $10 \mathrm{~cm}$, were set at intervals of $10 \mathrm{~cm}$ for the gas pore composition analysis in the filtering media.

This work shows the results obtained with a sample of the SS-MSW compost cover. The sample used had a pore volume of $36.5 \% v / v$, a $\mathrm{pH}$ of 8.1 and a water content of $30.4 \% w / w$. At a minimum of two weeks duration each, two case studies were set up: non-aerated column tests with pure methane $\left(99 \% v / v \mathrm{CH}_{4}\right)$, and an aerated test, using a gas mixture of $12 \% v / v \mathrm{CH}_{4}$ and $88 \% v / v$ of air. The tested flows were high to simulate biofilter applications: 41 and $206 \mathrm{~g} \mathrm{~m}^{-2} \mathrm{~d}^{-1}$ in the non-aerated tests; 82 and $312 \mathrm{~g} \mathrm{~m}^{-2} \mathrm{~d}^{-1}$ in the aerated biofilter simulation.

\subsection{Measurement and Monitoring Program}

In the monitoring program of the experimental biocover, implemented from August until November 2015, the conditions of the substrates used in the biocover, the soil gas concentrations and the gas emissions were detected.

Furthermore, during the monitoring period, meteorological data, including precipitation, air temperature, air humidity and atmospheric pressure, were continuously recorded by the weather station installed near the experimental biocover.

In each day of monitoring, samples of materials from each plot were taken at $15 \mathrm{~cm}$ depth. Total solids (TS) and the water content were analyzed by weighting the samples before and after drying at $105{ }^{\circ} \mathrm{C}$ for $24 \mathrm{~h}$ until a constant weight; VS were measured as loss of ignition at $550{ }^{\circ} \mathrm{C}$ and $\mathrm{pH}$ of the water suspension of the sampled substrates was measured too, according to ANPA (2001).

Soil gas concentration profiles were studied by the multilevel probe system previously described for both biocover and column tests. The concentrations of methane, carbon dioxide, oxygen and hydrogen sulfide were measured by a portable infrared gas analyzer (Ecoprobe 5, RS Dynamics, CZ) integrated with a $\mathrm{H}_{2} \mathrm{~S}-\mathrm{AH}$ Hydrogen Sulfide Sensor. For the analysis of soil gas emissions below 500 ppm, the gas was sampled by means of a foil bag and analyzed within $4 \mathrm{~h}$ with the micro-gas chromatograph (INFICON, Switzerland) according to the procedure described by Baldi et al. (2019) [42,43]. In order to get stable concentration measurements, the gas sampling was done with a pump speed of $0.251 \mathrm{~min}^{-1}$ and different measurement periods. Measurements were done starting from the internal probe and 
moving toward the external ones in a clockwise direction. In the column tests the pore gas composition was analyzed starting from the bottom. All readings were made in triplicate to ensure data repeatability.

Gas emissions were measured by the static accumulation chamber method using an infrared gas analyzer and a sample cell of 61 with an internal diameter of $200 \mathrm{~mm}$ [44]. In the field tests a regular grid was used for the flux measurements, and two measurements for each experimental plot and eight measurements in the external area in a clockwise direction were done [45]. All readings are made in triplicate to ensure data repeatability. The monitoring model applied here has been defined by other studies and then validated by the repeated field application $[12,19,27,45]$.

\section{5. $\mathrm{CH}_{4}$ Oxidation and Odor Mitigation Efficiencies}

Scheutz et al. (2009) [18] suggest that the use of mass ratios and mass balances for the $\mathrm{CH}_{4}$ and $\mathrm{CO}_{2}$ to derive $\mathrm{CH}_{4}$ oxidation is problematical because, in addition to production of $\mathrm{CO}_{2}$ via methanogenesis and $\mathrm{CH}_{4}$ oxidation, $\mathrm{CO}_{2}$ is also produced and consumed by multiple subsurface and near-subsurface processes (soil respiration, organic matter oxidation, photosynthesis). As such, in the present research the measured biogas emissions were used to qualitatively assess any effect of the biofiltration.

Nevertheless, to give an indication of the oxidation efficiency, the method proposed by Gebert et al. (2011) [14] was used in field and laboratory trials. According to the assumptions, in a biofilter with high $\mathrm{CH}_{4}$ loading and in temporary landfill covers, the volume of oxidized $\mathrm{CH}_{4}$ at a certain depth can be derived from the Equation (1):

$$
\frac{\left[\mathrm{CO}_{2}\right]_{L F G}+x}{\left[\mathrm{CH}_{4}\right]_{L F G}-x}=\frac{\left[\mathrm{CO}_{2}\right]_{i}}{\left[\mathrm{CH}_{4}\right]_{i}}
$$

where $x$ is the share of oxidized methane $(\% v / v) ;\left[\mathrm{CO}_{2}\right]_{L F G}$ and $\left[\mathrm{CH}_{4}\right]_{L F G}$ are the concentrations of methane and carbon dioxide in the landfill gas $(\% v / v)$, which correspond to the external probe measurements; $\left[\mathrm{CO}_{2}\right]_{i}$ and $\left[\mathrm{CH}_{4}\right]_{i}$ are methane and carbon dioxide concentrations at a $i$ depth $(\% v / v)$.

To assess the odor mitigation effects of the experimental biocovers, concentrations of the hydrogen sulfide measured in the internal and external probes will be compared.

\section{Results and Discussion}

\subsection{Climatic Conditions and Characteristics of the Filter Material}

Figure 1 shows the daily atmospheric temperatures and the atmospheric pressure logged during the monitoring period, and the average atmospheric temperature in each monitoring day. Data showed the seasonal decreasing of the atmospheric temperature during the trial (from 22 to $9^{\circ} \mathrm{C}$ ) and the fluctuation of the atmospheric pressure. 


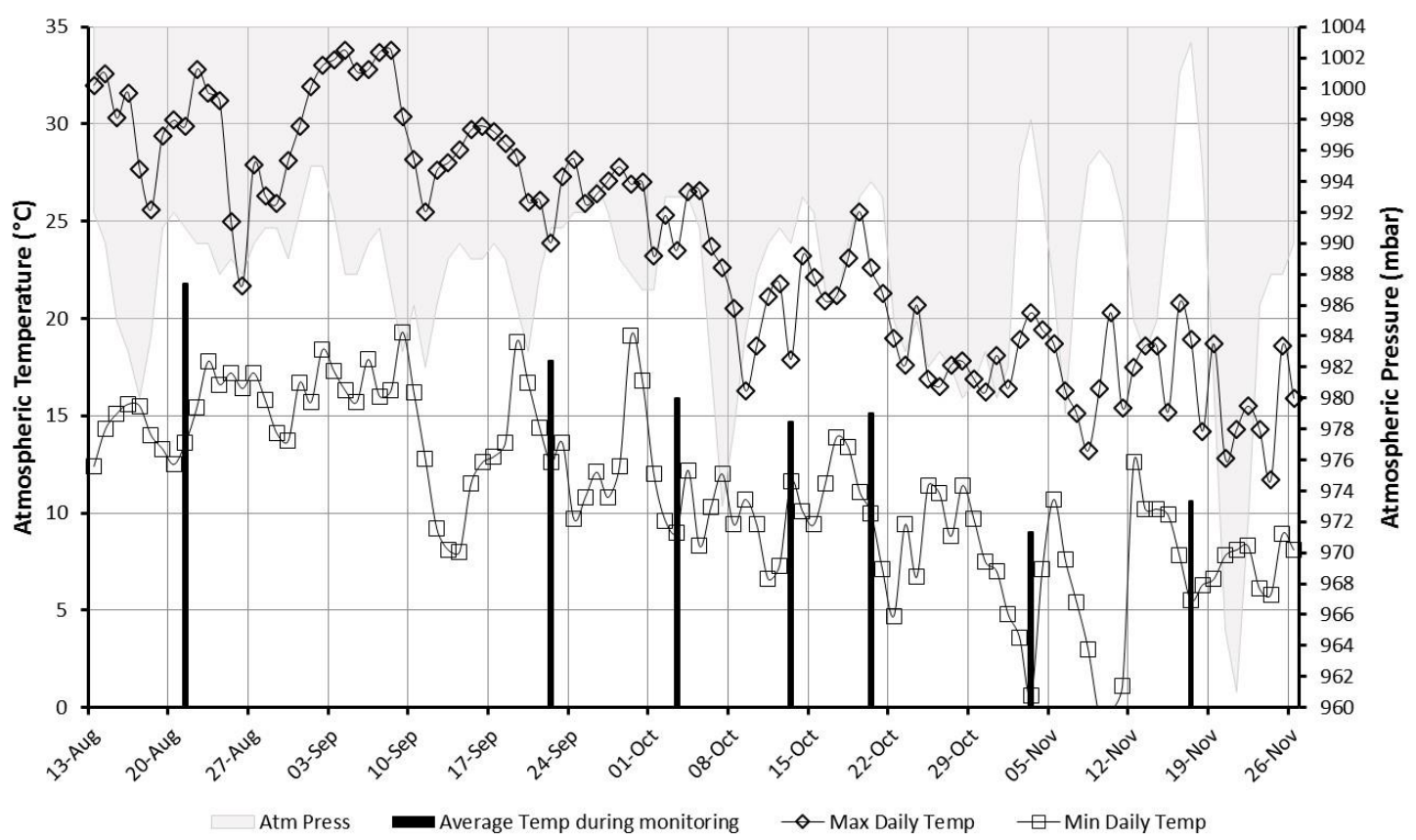

Figure 1. Atmospheric temperature and pressure at Casa Rota Landfill during the monitoring.

Figure 2 shows the relative humidity and the daily rainfall logged. As expected, precipitation was frequent and intensified in autumn months with the overall increasing of the relative humidity.

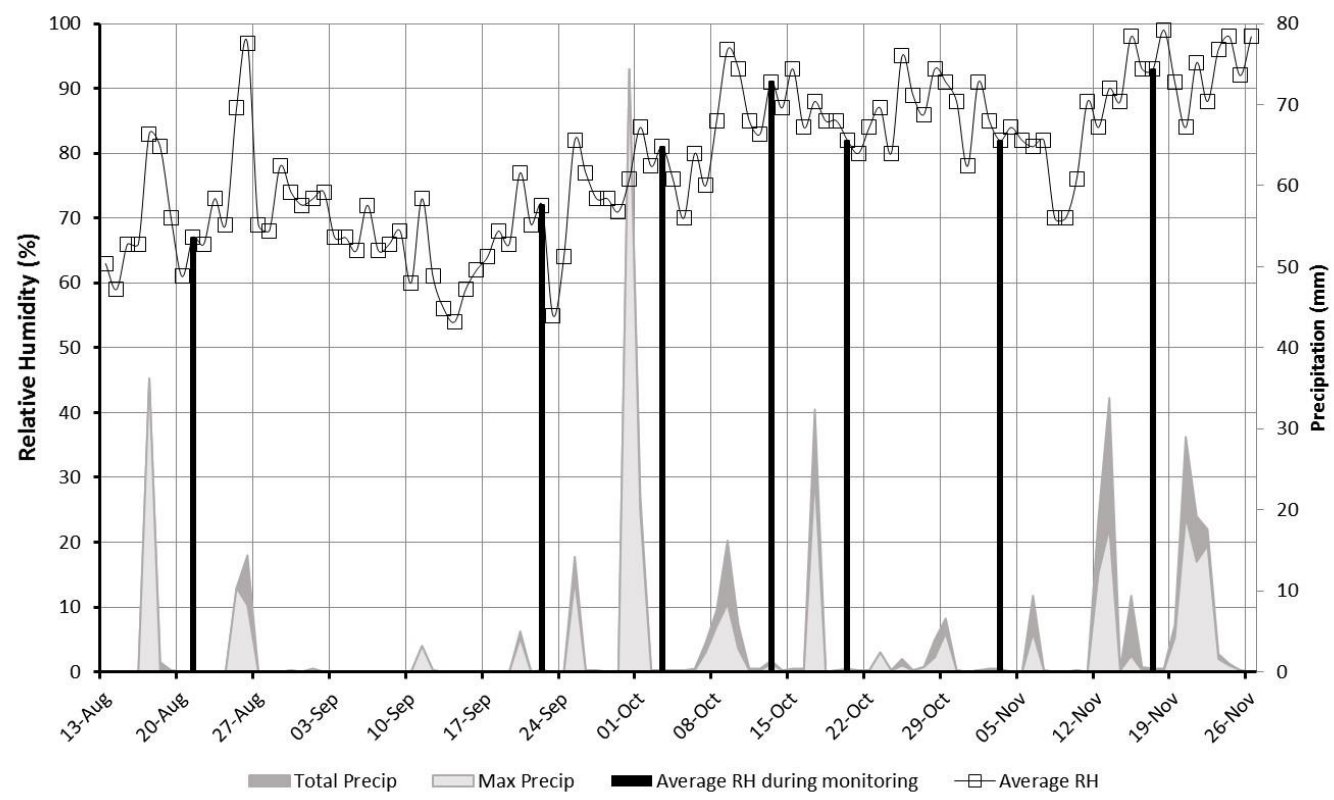

Figure 2. Relative humidity and precipitation at Casa Rota Landfill during the monitoring period.

In SS compost, MSW compost and SS-MSW compost biocovers, the $\mathrm{pH}$ ranged between 7.4 and 8.1, whereas the sand plot was lightly acidic, between 6 and 6.5. The water content values were always lower than $30 \% w / w$, except in the compost cover in the last monitoring day probably because of the heavy rainfall of the previous days. Overall, the SS-MSW compost cover maintained the highest water content vs. reduction among the three covers made of compost measured during the monitoring period; the values measured for the sand cover were constant and about $2 \% \mathrm{w} / \mathrm{d}$-typical for inert materials. 


\subsection{Gas Composition, Temperature and $\mathrm{CH}_{4} / \mathrm{CO}_{2}$ Ratio Profiles}

The gas profiles measured in each cover (Figure 3) showed that the methane oxidation mainly occurred between 45 and $85 \mathrm{~cm}$ of depth, depending on the porosity and density of the material.

In the sand cover, oxygen was present up to high depth $(95 \mathrm{~cm})$, while the concentrations of methane and carbon dioxide, with very similar profiles, decreased rapidly between 75 and $45 \mathrm{~cm}$ of depth and then remained constant.

Oxygen concentrations in the mixed cover SS-MSW compost was close to zero up to about $65 \mathrm{~cm}$ of depth, and above this depth, the concentrations of $\mathrm{CH}_{4}$ and $\mathrm{CO}_{2}$ rapidly decreased. In this cover, methanotrophic bacteria seemed to be active and concentrated in a narrow zone between 85 and $55 \mathrm{~cm}$ of depth. The gas concentrations measured in the superficial probes were close to the detection limit.

A gradual decrease of gas concentration was measured in the SS compost cover in which oxygen could diffuse to greater depths. Oxygen, a limiting factor for the development of bacterial communities, was present at all the depths investigated. $\mathrm{CH}_{4}$ and $\mathrm{CO}_{2}$ concentrations showed a rapid decrease between 55 and $95 \mathrm{~cm}$ depth in this cover too.

In the MSW compost plot, oxygen concentrations decreased up to $75 \mathrm{~cm}$ and reductions of methane concentration were measured between 35 and $85 \mathrm{~cm}$ of depth.

These trends were similar to those observed by other authors both in the case of biocovers and biowindows (in practice, in those cases where oxygen was present, it was because it infiltrated from the surface atmospheric air without a prior dilution of the incoming gas, such as in the biofilters) $[19,46,47]$.
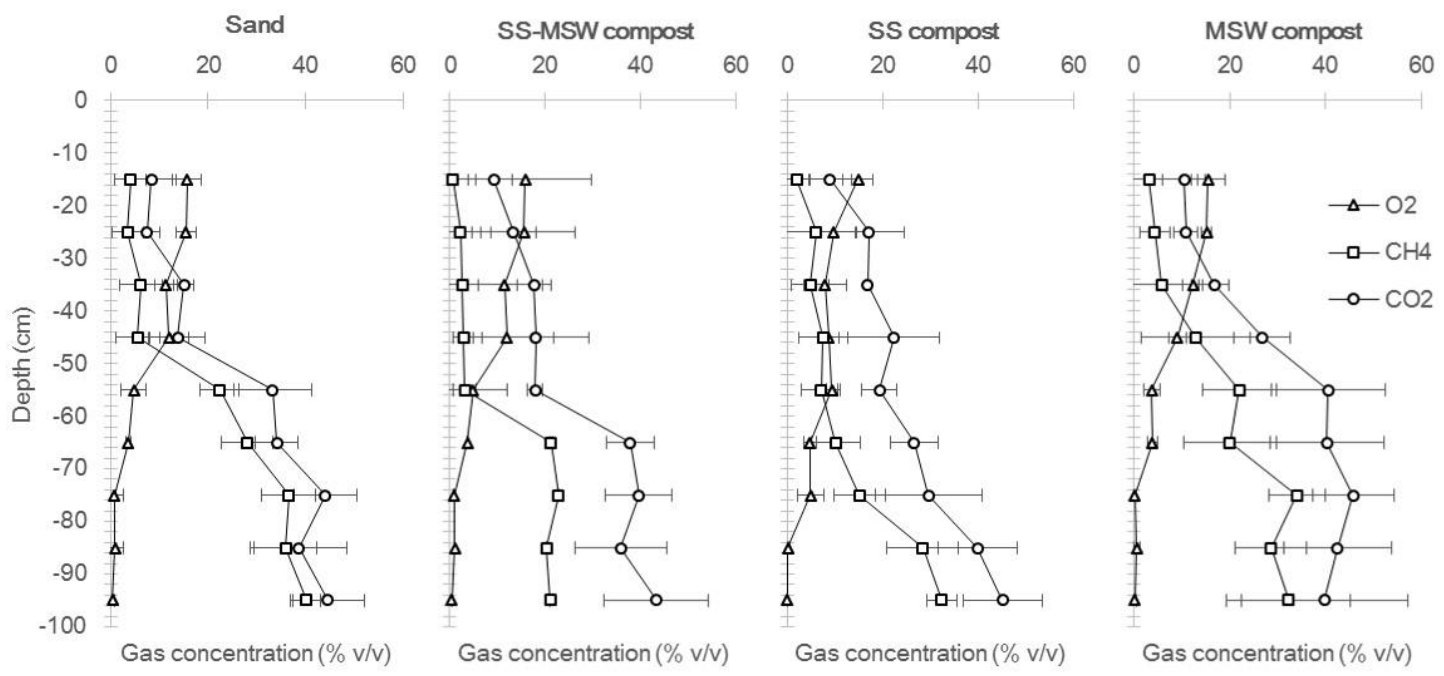

Figure 3. Average gas composition profiles.

Figure 4 compares the average profiles of temperature, $\mathrm{CH}_{4} / \mathrm{CO}_{2}$ ratio and $\mathrm{H}_{2} \mathrm{~S}$ concentration measured in each plot with reference to the average values calculated in the external probes (dashed line).

Results showed that the average temperatures followed a parabolic trend within all the experimental plots. Temperatures started to increase at $75 \mathrm{~cm}$ of depth with the vertex at $35 \mathrm{~cm}$ of depth and ranged between 19 and $36^{\circ} \mathrm{C}$; that could be considered an optimum range for methane oxidation $[19,23,25,48]$.

All the experimental covers showed a progressive decrease of the ratio as a function of depth. The decrease of this ratio is a strong indicator of the consumption of natural gas [48,49]. The measured ratio for the external probes was similar to those recorded at depths of $95 \mathrm{~cm}$ in each cover. The values of the ratios found in the surface probes were 0.1 in the mixed SS-MSW compost cover; values were between 0.2 and 0.3 in the SS compost and MSW compost covers; and the highest value was recorded in the sand cover (0.54). The decrease of the $\mathrm{CH}_{4} / \mathrm{CO}_{2}$ ratio in the MSW compost and SS-MSW compost covers occurred mainly at 55 and $75 \mathrm{~cm}$ of depth. In the sand cover, characterized by higher ratios, 
a decrease was recorded at $45 \mathrm{~cm}$ of depth; in the SS compost plot, the ratio decreased almost linearly with the depth.

Regarding the concentration of hydrogen sulfide, measurements showed that for all the covers, the concentrations in the higher probes were one order of magnitude lower than those recorded in the external probes. In fact, at $15 \mathrm{~cm}$ of depth, an average $\mathrm{H}_{2} \mathrm{~S}$ concentration of about $1 \mathrm{ppm}$ was present in the sand, in the SS compost and in the mixed MSW-SS compost covers. In the MSW compost cover, there was a concentration of $3 \mathrm{ppm} ; 15 \mathrm{ppm}$ of $\mathrm{H}_{2} \mathrm{~S}$ was found in the external probes.

It is important to notice that the concentrations of hydrogen sulfide measured at $95 \mathrm{~cm}$ depth were found to be different among the covers; in particular, an average concentration of $19 \mathrm{ppm}$ was measured in the sand cover, $48 \mathrm{ppm}$ in the mixed SS-MSW compost cover, $57 \mathrm{ppm}$ in SS compost and $64 \mathrm{ppm}$ in the MSW compost covers. This allows one to observe the effect of $\mathrm{H}_{2} \mathrm{~S}$ mitigation in biocovers, as other authors have found $[17,19,34]$.

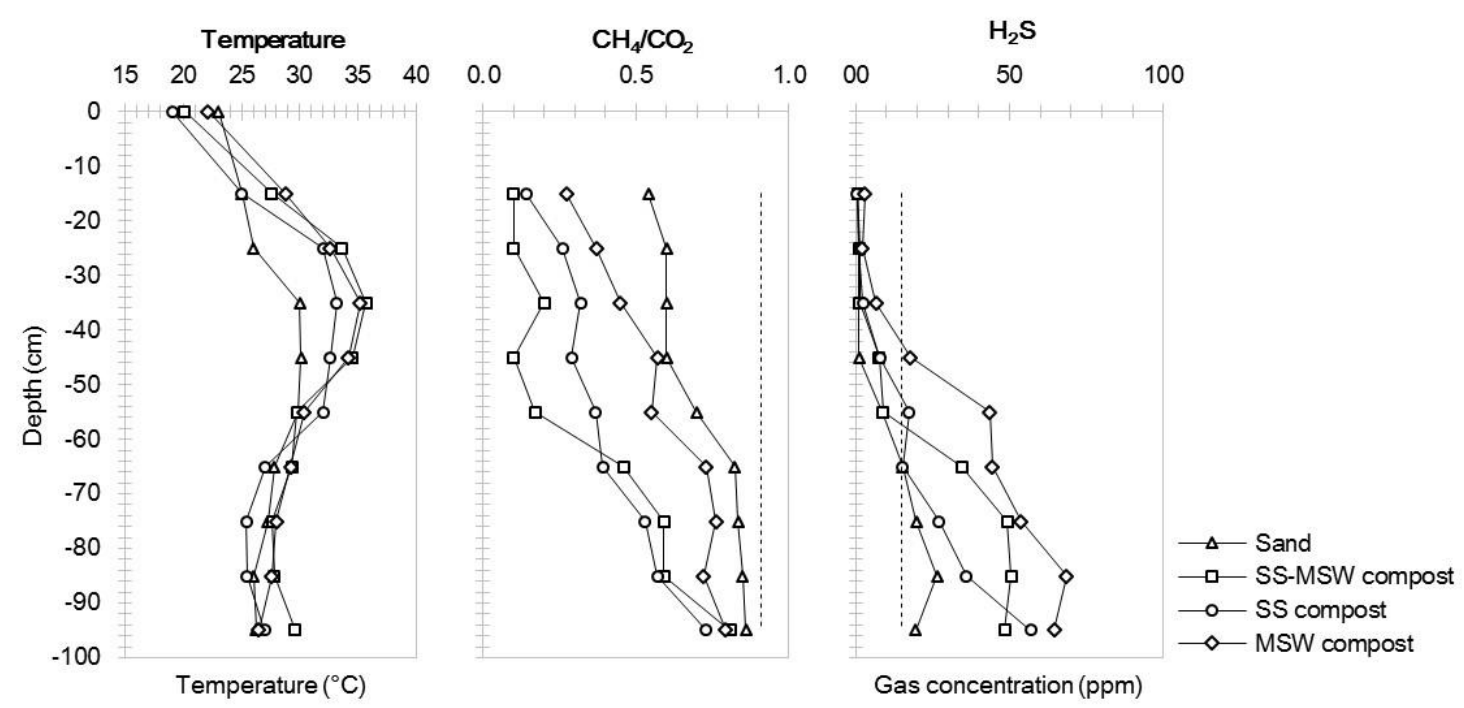

Figure 4. Average temperature, $\mathrm{CH}_{4} / \mathrm{CO}_{2}$ ratio and $\mathrm{H}_{2} \mathrm{~S}$ concentration profiles. Dotted lines represent the expected limits.

\section{3. $\mathrm{CH}_{4}$ Oxidation Efficiencies and Methane Emission Measurements}

Starting from every over gas concentration profiles, the oxidation efficiencies were calculated for each cover according to Gebert et al. (2011) [14] (Figure 5). The results underlined that in each plot, the efficiency decreased with depth, indicating that the presence of oxygen in the cover allowed for the development of methanotrophic bacteria. Data showed that high efficiency was achieved in the last monitoring days, probably due to a better acclimatization of methanotrophs. However, the worst performances were observed on November 17, when high values of water content were measured in the cover as a result of heavy rainfall. The average total efficiency (corresponding to $15 \mathrm{~cm}$ depth) of the mixed SS-MSW compost cover was registered to be the highest (75\%), followed by the efficiencies of SS and MSW compost plots ( $65 \%$ and $56 \%$ respectively). The maximum oxidation efficiencies were $100 \%$ in the SS-MSW compost plot, $96 \%$ in the SS compost and $81 \%$ in the MSW compost. 

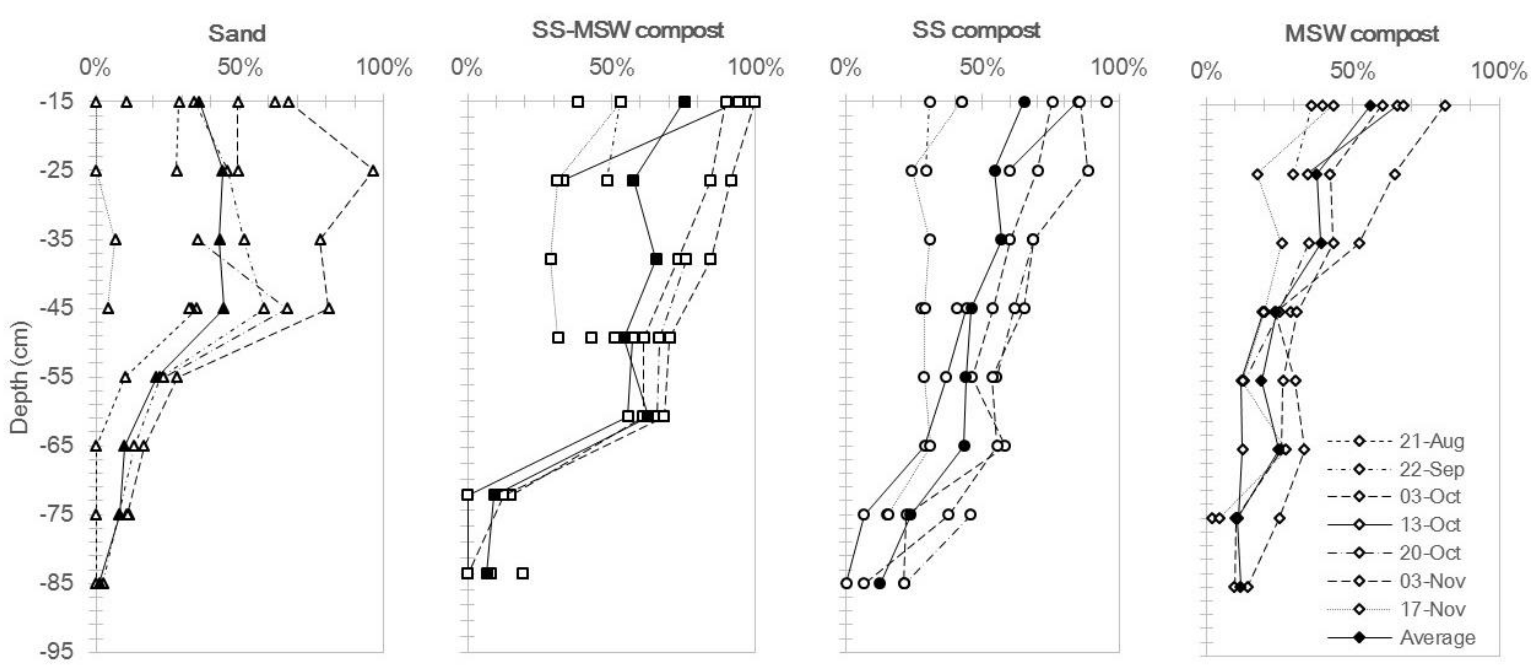

Figure 5. Methane oxidation efficiencies.

Figure 6 compares the average methane emissions measured inside and outside the trial biocover and the calculated average methane oxidation efficiency. Following a regular grid, about six flux measures inside and five measurements in the external surrounding area were done for each plot. Methane emissions in the SS compost cover were higher than the emissions measured in the other experimental plots, but overall the external methane emissions were the highest. Furthermore, as expected, higher methane emissions correspond to lower oxidation efficiencies.

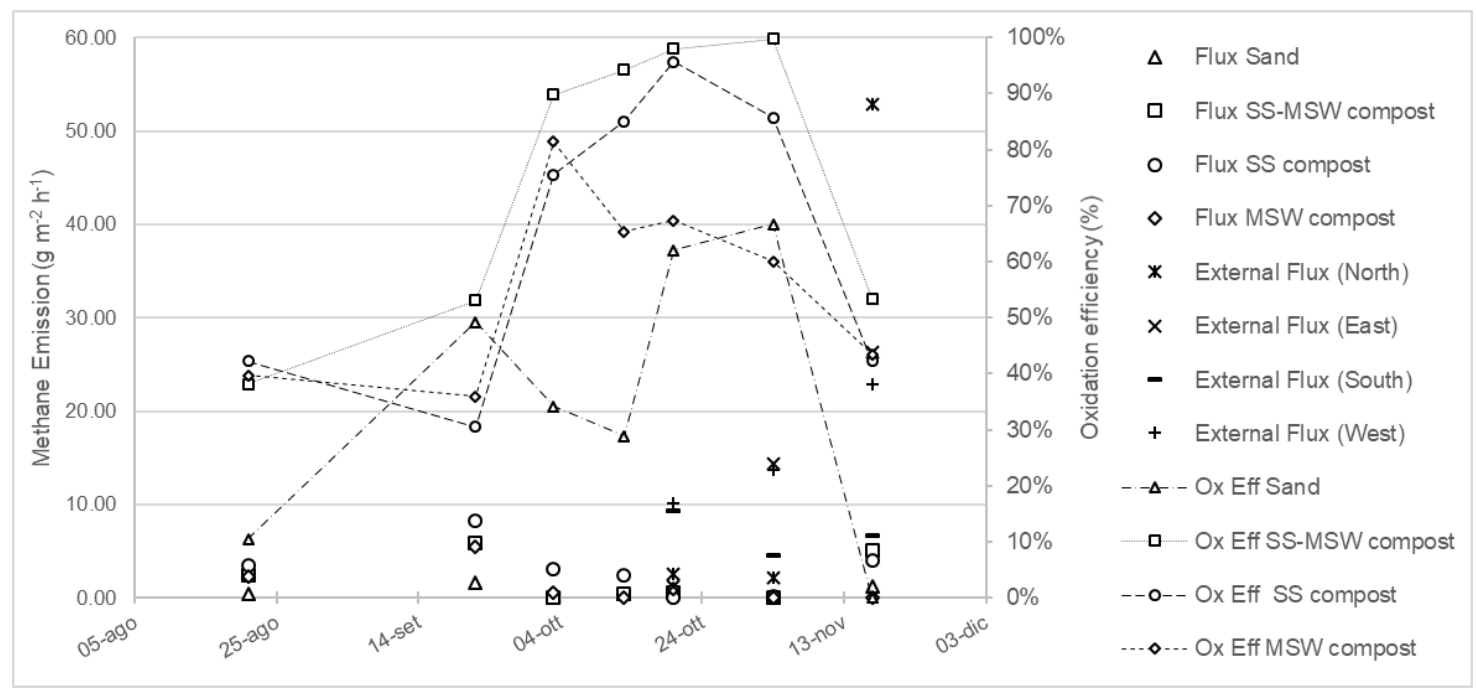

Figure 6. Methane emission measurements.

In Figure 6, it is possible to observe for the four different average filter media, different oxidation efficiencies of $\mathrm{CH}_{4}$ over the whole monitoring period, and in particular: $36 \% \pm 25 \%$ for sand, $75 \% \pm 26 \%$ for SS-MSW compost, $65 \% \pm 26 \%$ for SS compost and $56 \% \pm 17 \%$ for MSW compost. The best result of the compost with respect to sand was indeed expected, since the compost contains the nutrients for the organic substances and an excellent porosity that allows for the passage of oxygen into the pores, even at a depth of $65-75 \mathrm{~cm}[25,49]$.

\subsection{Column Tests}

In order to determine the specific yields of the filter materials used in the experimental plots, some laboratory tests on samples of SS-MSW compost extracted from the biocover were performed. The objective of the tests was also to estimate parameters useful to implementing other systems of 
biofiltration as active bio-filters. The tested flows were: 41 and $206 \mathrm{~g} \mathrm{~m}^{-2} \mathrm{~d}^{-1}$ in tests 1 and 2; and 82 and $312 \mathrm{~g} \mathrm{~m}^{-2} \mathrm{~d}^{-1}$ in test 3 and 4 .

Observing the gas composition profiles of test 1 and test 2 (Figure 7), it can be noticed that the oxygen diffuses into the filter material only up to $30 \mathrm{~cm}$ of depth. Furthermore, in test 1 with a lower methane inlet load, the methanotrophic bacteria seemed to be active and concentrated in a larger zone; the methane concentrations measured at $10 \mathrm{~cm}$ of depth were in fact lower than those detected in test 2 .

Gas composition profiles of the aerated tests, in which oxygen was supplied to inlet methane, show that the methane concentrations decrease with a linear trend with depth, probably because of the presence of active methanotrophic bacteria along the entire length of the column. The performances of the SS-MSW compost in test 3 and test 4, were similar, despite the increase of the inlet methane load.

The higher oxidation efficiencies were reached during the aerated tests as result of higher oxygen concentrations that allow for the activation of the entire column. In the aerated tests the higher efficiencies ( $94 \%$ and $87 \%$ in the tests 3 and 4 respectively) were reached between 30 and $20 \mathrm{~cm}$ depth; in the tests 1 and 2, the maximum efficiencies were more superficial. Furthermore, in tests 1 and 2, the oxidation efficiency decreases with increase of inlet load, and the aerated tests had comparable results.

The study in column tests shows that working with a gas diluted with incoming oxygen makes it possible to activate microbiological oxidation over the entire length of the column and thus increase oxidation efficiencies.
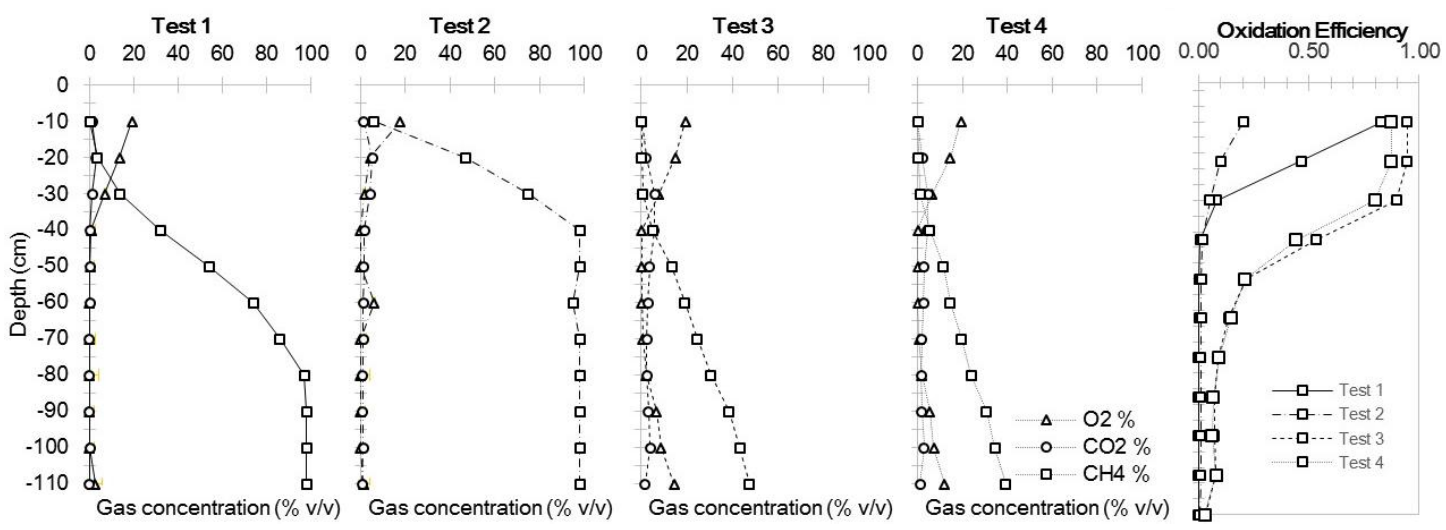

Figure 7. Average gas composition profiles and methane oxidation efficiencies in the column tests.

\section{Conclusions}

Field and laboratory investigations were carried out to study the possibility of mitigating biogas emissions' impacts by means of biofiltration systems. In particular, four pilot-scale biocovers made of compost from a source-selected organic fraction (SS compost), MSW compost from a mechanical biological treatment plant, mixed compost (SS-MSW compost) and sand were constructed and monitored in the daily cover area of the Casa Rota Landfill.

Results showed that the biocovers were an effective system to reduce landfill gas emission, especially for the mixed SS-MSW compost cover. Anyway, the worst performances were observed with no good atmospheric conditions and with low oxygen concentrations, proving that further investigations are necessary for the real applicability of biofiltration systems.

From the results it is also possible to conclude that compost is an excellent medium filter for measuring the effects of microbiological oxidation of methane emitted from landfill covers.

In laboratory trials, the methane oxidation efficiencies of the tested SS-MSW compost samples were higher when air was added to the inlet gas. Results hence suggested that, in real active biofilter systems, gas suction could be properly increased. 
Author Contributions: Conceptualization, I.P. and R.I.; methodology, I.P.; software, I.P.; validation, I.P. and R.I.; formal analysis, I.P.; investigation, I.P.; resources, I.P.; data curation, I.P.; writing一 original draft preparation, I.P.; writing-review and editing, I.P. and R.I.; visualization, I.P.; supervision, I.P.; project administration, I.P.; funding acquisition, I.P. All authors have read and agreed to the published version of the manuscript.

Funding: This research was cofunded by Centro Servizi Ambiente Impianti S.p.A., and the APC was funded by DESTEC-UNIPI.

Acknowledgments: The authors would like to thank all the workers of Centro Servizi Ambiente Impianti S.p.A. for their support for this research. The authors would like to thank Donata Bacchi and Francesco Baldi for their help during the field sampling.

Conflicts of Interest: The authors declare no conflict of interest.

\section{References}

1. He, R.; Xia, F.-F.; Wang, J.; Pan, C.-L.; Fang, C.-R. Characterization of adsorption removal of hydrogen sulfide by waste biocover soil, an alternative landfill cover. J. Hazard. Mater. 2011, 186, 773-778. [CrossRef] [PubMed]

2. Global Warming Potentials (IPCC Second Assessment Report)|UNFCCC. Available online: https://unfccc.int/process/transparency-and-reporting/greenhouse-gas-data/greenhouse-gas-dataunfccc/global-warming-potentials (accessed on 31 March 2020).

3. Waste Statistics-Statistics Explained. Available online: https://ec.europa.eu/eurostat/statistics-explained/ index.php?title=Waste_statistics (accessed on 31 March 2020).

4. Pecorini, I.; Baldi, F.; Bacchi, D.; Carnevale, E.A.; Corti, A. Leaching behaviour of hazardous waste under the impact of different ambient conditions. Waste Manag. 2017, 63, 96-106. [CrossRef] [PubMed]

5. ISPRA: Catasto Nazionale Rifiuti. Available online: https://www.catasto-rifiuti.isprambiente.it/index.php? pg=\&width=1920\&height $=1080$ (accessed on 31 March 2020).

6. Rettenberger, G. Collection and Disposal of Landfill Gas. In Solid Waste Landfilling; Elsevier: Amsterdam, The Netherlands, 2018; pp. 449-462. ISBN 978-0-12-818336-6.

7. Sadasivam, B.Y.; Reddy, K.R. Landfill methane oxidation in soil and bio-based cover systems: A review. Rev. Environ. Sci. Biotechnol. 2014, 13, 79-107. [CrossRef]

8. Bacchi, D.; Bacci, R.; Ferrara, G.; Lombardi, L.; Pecorini, I.; Rossi, E. Life Cycle Assessment (LCA) of landfill gas management: Comparison between conventional technologies and microbial oxidation systems. Energy Procedia 2018, 148, 1066-1073. [CrossRef]

9. Rettenberger, G. Utilization of Landfill Gas and Safety Measures. In Solid Waste Landfilling; Elsevier: Amsterdam, The Netherlands, 2018; pp. 463-476. ISBN 978-0-12-818336-6.

10. Lombardi, L.; Carnevale, E.A.; Pecorini, I. Experimental evaluation of two different types of reactors for CO2 removal from gaseous stream by bottom ash accelerated carbonation. Waste Manag. 2016, 58, 287-298. [CrossRef] [PubMed]

11. Felske, C.; Haubrichs, R.; Widmann, R. Engineering strategies for efficient methane oxidation in landfill cover liners and biofilter systems. In Proceedings of the Sardinia 2005. Tenth International Waste Management and Landfill Symposium, S. Margherita di Pula, Cagliari, Italy, 3-7 October 2005.

12. Pecorini, I.; Bacchi, D.; Ferrara, G.; Rossi, E.; Caselli, R.L.; Zipoli, L.; Menghetti, F. Biofiltration prototyes for methane oxidation in landfill aftercare and abatement of NMVOCs and odorous compounds. Procedia Environ. Sci. Eng. Manag. 2017, 4, 173-181.

13. Rossi, E.; Pecorini, I.; Iannelli, R. Risk assessment of a methane oxidizing biofilter for reducing landfill gas emissions from a post-closure landfill. Procedia Environ. Sci. Eng. Manag. 2019, 6, 209-219.

14. Gebert, J.; Röwer, I.U.; Scharff, H.; Roncato, C.D.L.; Cabral, A.R. Can soil gas profiles be used to assess microbial CH4 oxidation in landfill covers? Waste Manag. 2011, 31, 987-994. [CrossRef]

15. Cassini, F.; Scheutz, C.; Skov, B.H.; Mou, Z.; Kjeldsen, P. Mitigation of methane emissions in a pilot-scale biocover system at the AV Miljø Landfill, Denmark: 1. System design and gas distribution. Waste Manag. 2017, 63, 213-225. [CrossRef]

16. Capanema, M.A.; Cabana, H.; Cabral, A.R. Reduction of odours in pilot-scale landfill biocovers. Waste Manag. 2014, 34, 770-779. [CrossRef]

17. Jung, H.; Oh, K.-C.; Ryu, H.-W.; Jeon, J.-M.; Cho, K.-S. Simultaneous mitigation of methane and odors in a biowindow using a pipe network. Waste Manag. 2019, 100, 45-56. [CrossRef] [PubMed] 
18. Scheutz, C.; Kjeldsen, P.; Bogner, J.E.; De Visscher, A.; Gebert, J.; Hilger, H.A.; Huber-Humer, M.; Spokas, K. Microbial methane oxidation processes and technologies for mitigation of landfill gas emissions. Waste Manag. Res. 2009, 27, 409-455. [CrossRef] [PubMed]

19. Pecorini, I.; Rossi, E.; Iannelli, R. Mitigation of Methane, NMVOCs and Odor Emissions in Active and Passive Biofiltration Systems at Municipal Solid Waste Landfills. Sustainability 2020, 12, 3203. [CrossRef]

20. Pecorini, I.; Albini, E.; Rossi, E.; Iannelli, R.; Raco, B.; Lippo, G. Landfill mining: A case study on characterization of excavated waste. Procedia Environ. Sci. Eng. Manag. 2018, 5, 153-158.

21. Rossi, E.; Pecorini, I.; Iannelli, R. Methane oxidation of residual landfill gas in a full-scale biofilter: Human health risk assessment of volatile and malodours compound emissions. Environ. Sci. Pollut. Res. 2020, 1-13. [CrossRef] [PubMed]

22. Einola, J.-K.M.; Karhu, A.E.; Rintala, J.A. Mechanically-biologically treated municipal solid waste as a support medium for microbial methane oxidation to mitigate landfill greenhouse emissions. Waste Manag. 2008, 28, 97-111. [CrossRef]

23. Gebert, J.; Groengroeft, A.; Miehlich, G. Kinetics of microbial landfill methane oxidation in biofilters. Waste Manag. 2003, 23, 609-619. [CrossRef]

24. Borjesson, G.; Sundh, I.; Svensson, B. Microbial oxidation of CH4 at different temperatures in landfill cover soils. FEMS Microbiol. Ecol. 2004, 48, 305-312. [CrossRef]

25. Mor, S.; De Visscher, A.; Ravindra, K.; Dahiya, R.P.; Chandra, A.; Van Cleemput, O. Induction of enhanced methane oxidation in compost: Temperature and moisture response. Waste Manag. 2006, 26, 381-388. [CrossRef]

26. Einola, J.-K.M.; Kettunen, R.H.; Rintala, J.A. Responses of methane oxidation to temperature and water content in cover soil of a boreal landfill. Soil Biol. Biochem. 2007, 39, 1156-1164. [CrossRef]

27. Rossi, E.; Frasi, N.; Pecorini, I.; Ferrara, G. Methane oxidation efficiency and NMVOCs reduction in a full-scale passive bioifltration system for the treatment of residual landfill gas. Procedia Environ. Sci. Eng. Manag. 2018, $5,147-152$.

28. Roncato, C.D.; Létourneau, M.; Cabral, A.R. Comparison between Field and Laboratory Methane Oxidation Rates. In Proceedings of the GeoFlorida 2010; American Society of Civil Engineers: Orlando, FL, USA, 2010; pp. 2906-2915.

29. Scheutz, C.; Pedersen, R.B.; Petersen, P.H.; Jørgensen, J.H.B.; Ucendo, I.M.B.; Mønster, J.G.; Samuelsson, J.; Kjeldsen, P. Mitigation of methane emission from an old unlined landfill in Klintholm, Denmark using a passive biocover system. Waste Manag. 2014, 34, 1179-1190. [CrossRef] [PubMed]

30. Chan, A.S.K.; Parkin, T.B. Evaluation of potential inhibitors of methanogenesis and methane oxidation in a land ${ }^{\circledR} 11$ cover soil. Soil Biol. Biochem. 2000, 32, 1581-1590. [CrossRef]

31. Wilshusen, J.H.; Hettiaratchi, J.P.A.; De Visscher, A.; Saint-Fort, R. Methane oxidation and formation of EPS in compost: Effect of oxygen concentration. Environ. Pollut. 2004, 129, 305-314. [CrossRef] [PubMed]

32. Pecorini, I.; Iannelli, R. Characterization of Excavated Waste of Different Ages in View of Multiple Resource Recovery in Landfill Mining. Sustainability 2020, 12, 1780. [CrossRef]

33. Barbusinski, K.; Kalemba, K.; Kasperczyk, D.; Urbaniec, K.; Kozik, V. Biological methods for odor treatment-A review. J. Clean. Prod. 2017, 152, 223-241. [CrossRef]

34. Liu, Y.; Lu, W.; Wang, H.; Huang, Q.; Gao, X. Odor impact assessment of trace sulfur compounds from working faces of landfills in Beijing, China. J. Environ. Manag. 2018, 220, 136-141. [CrossRef]

35. Dever, S.; Swarbrick, G.E.; Stuetz, R.M. (19) (PDF) Handbook for the Design, Construction, Operation, Monitoring and Maintenance of a Passive Landfill Gas Drainage and Biofiltration System. Available online: https://www.researchgate.net/publication/239998633_Handbook_for_the_design_construction_operation_ monitoring_and_maintenance_of_a_passive_landfill_gas_drainage_and_biofiltration_system (accessed on 20 March 2020).

36. Dever, S.A.; Swarbrick, G.E.; Stuetz, R.M. Passive drainage and biofiltration of landfill gas: Australian field trial. Waste Manag. 2007, 27, 277-286. [CrossRef] [PubMed]

37. Majdinasab, A.; Yuan, Q. Performance of the biotic systems for reducing methane emissions from landfill sites: A review. Ecol. Eng. 2017, 104, 116-130. [CrossRef]

38. EUR-Lex-31999L0031-EN. Available online: https://eur-lex.europa.eu/legal-content/EN/TXT/HTML/?uri= CELEX:31999L0031\&from=EN (accessed on 29 April 2020). 
39. Jugnia, L.-B.; Cabral, A.R.; Greer, C.W. Biotic methane oxidation within an instrumented experimental landfill cover. Ecol. Eng. 2008, 33, 102-109. [CrossRef]

40. Adani, F.; Ubbiali, C.; Generini, P. The determination of biological stability of composts using the Dynamic Respiration Index: The results of experience after two years. Waste Manag. 2006, 26, 41-48. [CrossRef] [PubMed]

41. Albini, E.; Pecorini, I.; Ferrara, G. Evaluation of biological processes performances using different stability indices. Procedia Environ. Sci. Eng. Manag. 2019, 6, 1-10.

42. Baldi, F.; Iannelli, R.; Pecorini, I.; Polettini, A.; Pomi, R.; Rossi, A. Influence of the pH control strategy and reactor volume on batch fermentative hydrogen production from the organic fraction of municipal solid waste. Waste Manag. Res. 2019, 37, 478-485. [CrossRef] [PubMed]

43. Baldi, F.; Pecorini, I.; Iannelli, R. Comparison of single-stage and two-stage anaerobic co-digestion of food waste and activated sludge for hydrogen and methane production. Renew. Energy 2019, 143, 1755-1765. [CrossRef]

44. Pecorini, I. Sistemi di Monitoraggio Delle Emissioni Diffuse di Biogas di Discarica per la Ottimizzazione del Sistema di Gestione. Ph.D. Thesis, Università Degli Studi di Firenze, Firenze, Italy, 2010.

45. Raco, B.; Battaglini, R.; Lelli, M. Gas emission into the atmosphere from controlled landfills: An example from Legoli landfill (Tuscany, Italy). Environ. Sci. Pollut. Res. 2010, 17, 1197-1206. [CrossRef]

46. Thomasen, T.B.; Scheutz, C.; Kjeldsen, P. Treatment of landfill gas with low methane content by biocover systems. Waste Manag. 2019, 84, 29-37. [CrossRef]

47. Scheutz, C.; Cassini, F.; De Schoenmaeker, J.; Kjeldsen, P. Mitigation of methane emissions in a pilot-scale biocover system at the AV Miljø Landfill, Denmark: 2. Methane oxidation. Waste Manag. 2017, 63, $203-212$. [CrossRef]

48. Huber-Humer, M.; Gebert, J.; Hilger, H. Biotic systems to mitigate landfill methane emissions. Waste Manag. Res. 2008, 26, 33-46. [CrossRef]

49. Huber-Humer, M.; Tintner, J.; Böhm, K.; Lechner, P. Scrutinizing compost properties and their impact on methane oxidation efficiency. Waste Manag. 2011, 31, 871-883. [CrossRef]

(C) 2020 by the authors. Licensee MDPI, Basel, Switzerland. This article is an open access article distributed under the terms and conditions of the Creative Commons Attribution (CC BY) license (http://creativecommons.org/licenses/by/4.0/). 